\title{
Koraszülöttség és fejlődési kimenet
}

\section{Gráf Rózsa}

ELTE Bárczi Gusztáv Gyógypedagógiai Kar Atípusos Viselkedés és Kogníció Gyógypedagógiai Intézet

A koraszülött gyermekek élete nagy megpróbáltatásokkal indul, de legtöbben közülük győztesként kerülnek ki ebböl a küzdelemböl. Köszönhetően a gyorsan fejlődő orvosi technikának, magas szintü szaktudásnak és annak az elkötelezett szakmaiságnak, amit egy-egy intenzív neonatális centrumban láthatunk. Azonban, hogy milyen életminőséget érnek el a későbbiekben ezek a gyerekek, ahhoz a társ-szakmáknak is hozzá kell tenni a hasonlóan magas szintü tudást és gyakorlatot. A fejlődési kimenettel foglalkozó nemzetközi irodalmakat gyüjtöttem össze a cikkben és kiegészítettem saját kutatási adatainkkal.

Kulcsszavak: koraszülöttség, fejlödési kimenet, társuló betegségek, fejlödési mutatók, koraszülöttek olvasás- és helyesírás-teljesítménye

A nagyon kis születési súlyú koraszülött gyermekek életben maradása érettségüktől és attól a környezettől - főként pedig annak felkészültségétől - függ, ahova születnek. A megszületés pillanatában a legtöbb koraszülött gyermek szervezete nem működőképes. Szükség van a korszerü, intenzív koraszülött ellátásra, amely megfelelő műszaki felszereltséget és speciálisan képzett egészségügyi személyzetet jelent. A koraszülött osztályokon olyan újszülötteket kell életben tartani, akik nem betegek, de a szervezetük felkészületlen az extrauterin körülmények közötti müködésre. Az újszülött intenzív terápia fejlődése gyökeresen változtatta meg a kis születési testtömegű koraszülöttek életkilátásait. A javuló terhesgondozás, a kíméletes szülésvezetés, a megfelelő szállítás, az élettani paraméterek korszerü monitorozása, a surfactan-terápia rutinszerü alkalmazása, a modern lélegeztetési módok, az új típusú gyermeksebészeti és szívsebészeti technikák bevezetése, az adekvát posztoperatív ellátás, a megfelelő enterális és parenterális táplálás, valamint a koraszülöttek ápolásában alkalmazott ún. „minimal handling"-elv a perinatális morbiditás és mortalitás jelentős javulását eredményezte. A magas szintü intenzív ellátás többnyire minőségi túlélést eredményez (Katona és Orvos, 2005).

A gyerekek több hónapot töltenek az intenzív osztályokon, amíg elérik azt a súlyt, vegetatív stabilitást, megfelelő gyarapodási ütemet, amivel hazaengedik őket. Az ellátás költséges és hosszú ideig tart. Ma már a szülök jelen lehetnek a koraszülött osztályokon, kézbe vehetik a kicsiket, részt vehetnek a gondozási folyamatokban. Azonban az első élethetek félelmei, aggodalmai mélyen beivódnak a szülők tudatába.

Hazánkban az élve születések 8-10 százaléka koraszülés. Ez a nyugati országok viszonylatában magasnak tekinthető, hiszen Nyugat-és Észak-Európában ez az arány $4 \%$. A probléma továbbra is népbetegségnek számít Magyarországon (www. koraszulottlap.hu).

2010-ben a világon csaknem 15 millió gyermek született a 37. gesztációs hét előtt, azaz minden 9. gyermek. A koraszülések száma világszerte növekszik. A WHO által közzétett adatok szerint Magyarországon 2010-ben 8,6\% volt, amely 1990 és 2010 között évente átlagosan 0,5\%-kal emelkedett. Magyarországon minden 10. gyermek koraszülöttként jön világra (www.weborvos.hu). 


\section{A koraszülöttség hatása az értelmi fejlődésre}

Az értelmi fejlődésre, az intelligencia alakulására vonatkozóan rendkívül ellentmondásos adatokat találhatunk a szakirodalomban. Vannak kutatások, amelyek koraszülött gyermekek intellektusának különböző mértékű károsodásáról számolnak be az időre született gyerekek csoportjához mérten, míg más kutatások szerint nincs jelentős különbség a két csoport között (Kalmár, 2007).

Saját kutatási adataink 8-11 éves kor közötti koraszülött, diszlexiás és jól olvasó gyermekekre vonatkozóan vannak. A koraszülött gyerekek mindannyian $1500 \mathrm{~g}$ alatti születési testtömegü, negatív neurológiai státuszú, mérsékelt rizikójú koraszülöttek. A 28-33. gesztációs hétre születtek, 990-1350 g közötti születési testtömeggel. Az intelligenciavizsgálatot WISCIV (Wechsler Intelligence Scale for Children-Fourth Edition) teszttel végeztük.

A WISC-IV teszt értelmezését jelenleg is David Wechsler intelligencia-felfogása határozza meg alapvetően. Wechsler szerint az intelligencia „egy egészként jellemzi a személy magatartását, ugyanakkor specifikus is, mivel egymástól eltérő elemekből, képességekből épül fel” (Nagyné, 2008. 8. o.). A szubtesztek az intelligencia kognitív vonatkozásaira irányulnak, mint a verbális megértés, perceptuális szervezés, absztrakt gondolkodás, számolás, emlékezet, feldolgozási sebesség. Az egyes szubtesztek teljesítéséhez számos kognitív képesség megfelelő müködése szükséges.

A WISC-IV szerkezeti felépítését jelentően befolyásolta a fluid és a kristályos intelligenciát elkülönítő Cattel-Horn-Carroll-féle elmélet. A fluid intelligencia olyan képesség, amely a problémamegoldásban, jelentéstulajdonításban és a különböző dolgok közötti kapcsolatok felismerésében játszik fontos szerepet, független a megszerzett tudástól. A performációs feladatok többsége ezt az intelligenciatípust méri. A kristályos intelligencia viszont az ismeretek, a megszerzett készségek alkalmazását foglalja magába, többnyire a verbális feladatok mérik (Nagyné, 2008).

A WISC-IV. kiértékelése során öt összesített csoportpontot nyerhetünk. Ez a változat is ad Teljes teszt IQ-t, ami az átfogó kognitív képességeket tükrözi. Továbbá négy kiegészítő összesített mutatót is kaphatunk, amelyek a teljesítményt az egymástól elkülönülő kognitív müködések terén mutatják. Ezek a Verbális megértés Index (Vml), a Perceptuális következtetés Index (Pkl), a Munkamemória Index (Mml) és a Feldolgozási sebesség Index (Fsl).

Az elemzések során az alábbi mutatókat használtuk:

A Verbális megértés Index (VmI) szubtesztjei:

- Közös jelentés (Kj), ami a verbális gondolkodást és fogalomalkotást, a lényeges és lényegtelen tulajdonságok elkülönítését, a verbális kifejezőkészséget méri.

- Szókincs (Szk), a szóismeret, a verbális fogalomalkotó képesség, az általános tudás, a tanulási készség, valamint a nyelvi fejlettség mérésére szolgál.

- Általános megértés (Am), a verbális megértés, gyakorlati ítélőképesség próbája, verbális problémamegértés szintjét jelzi.

A Perceptuális következtetés Index (Pkl) szubtesztjei:

- Mozaik próba: az absztrakt vizuális elemzésen alapul, a téri konstrukciós képességet méri, de lényeges elemei a mozgás kivitelezés és stratégiaszervezés is. Képi fogalomalkotás (Kf) az absztrakt gondolkodás szintjét méri.

- Mátrix $(\mathrm{Mx})$ a vizuális információ feldolgozását, az absztrakt gondolkodást, analógiás, szeriális gondolkodást tükrözi.

\section{A Munkamemória szubtesztjei (Mml):}

- Számterjedelem, ami az emlékezeti és figyelem terjedelem mérésére szolgál, illetve a fordított sorrendnél a munkamemória, téri vizuális képzelőerő mérőszáma.

- Betű-szám szekvencia az információ emlékezetben tartásának képességét és az ezzel való műveletvégzés szintjét méri. 
A Feldolgozási sebesség Index (Fsl) szubtesztjei:

- Kódolás: pszichomotoros gyorsaság, tanulási készség, vizuomotoros koordináció, kognitív rugalmasság szükséges a jó teljesítményhez.

- Szimbólumkeresés: a feldolgozási sebességen, a tervezésen, a döntésen, valamint a monitorozáson alapul.

\begin{tabular}{|l|c|c|c|c|c|}
\hline \multicolumn{1}{|c|}{ Csoport } & Vml & Pkl & Mml & Fsl & TtIQ \\
\hline Koraszülött (23) & 103,9 & 100,8 & 98,8 & 107,0 & 103,2 \\
\hline Diszlexiás (27) & 103,2 & 100,6 & 92,6 & 98,3 & 99,4 \\
\hline Jól olvasó (30) & 112,8 & 111,0 & 105,3 & 109,4 & 112,8 \\
\hline 1. táblázat: Intelligenciamutatók
\end{tabular}

Számos korábban említett kutatás eredményeihez hasonlóan mi is jelentősen alacsonyabb intelligencia mutatókat kaptunk a koraszülött csoportban. A Teljes teszt IQ 9 ponttal alacsonyabb, mint a kontroll csoporté, a Perceptuális következtetés Index pedig 11 ponttal alacsonyabb. A feldolgozási sebesség index közelíti meg leginkább a kontroll csoport átlagát. Az alacsonyabb intelligencia hányados hozzájárulhat a koraszülötteknél gyakran megjelenő iskolai teljesítményproblémákhoz.

\section{Az előrejelezhetőség megbízhatósága dilemma}

Az egyre magasabb életkorig jutó longitudinális vizsgálatok tapasztalatai is azt a tényt erősítik meg, hogy a születés körüli komplex biológiai, orvosi mutatók csak rövid időre adnak megbízható előrejelzést, és megbízhatóságuk többnyire az első életévekre vonatkozik. A koraszülöttségnek a fejlődésre gyakorolt hatását egyelőre csak általánosságban ismerjük, és a rendelkezésünkre álló adatok a folyamatok megértéséhez nem elegendőek (Beckwith és Rodning, 1991).

Koraszülöttek fejlödésmenetével kapcsolatban felvetődik a kérdés, hogy stabilitás jellemző-e, vagy egyenletes előre haladás, esetleg fokozott javulás, vagy éppen idővel a fejlődés lelassulása várható-e. Korábban az a nézet uralkodott, hogy a koraszülöttek fokozatosan felzárkóznak (Ungerer és Siegman, 1983; Miller, Dubowitz és Palmer, 1984 in Kalmár, 2007). Többen megkérdőjelezték ezt, mivel az iskoláskor kezdetén, illetve az iskolában váratlan nehézségeket észleltek (Klein et al, 1985; Zubrick, Macartney és Stanley, 1988 in Kalmár, 2007).

Ezzel kapcsolatos az a saját kutatásunk, amelyet a Péterfy Sándor Utcai Kórház Neonatológiai és Csecsemő Osztályán 1999-2008 között kezelt koraszülött gyerekekkel végeztünk. Az elemzésbe az $1500 \mathrm{~g}$ alatti születési testtömegü (igen kis születési testtömeg), negatív neurológiai státuszú, mérsékelt rizikójú koraszülötteket, és a fejlődési kimenet szempontjából fokozottan veszélyeztetett $1500 \mathrm{~g}$ alatti, igen kis születési testtömegü, negatív neurológiai státuszú, mérsékelt rizikójú BPD-s gyerekeket vontuk be.

\begin{tabular}{|l|c|c|c|c|}
\hline \multicolumn{1}{|c|}{ Csoport } & \multicolumn{2}{c|}{ BPD-s } & \multicolumn{2}{c|}{ Nem BPD-s } \\
\hline Nem & fiú & lány & fiú & lány \\
\hline Gesztációs idő (hét) & $26,83(1,67)$ & $26,32(1,57)$ & $29,7(2,51)$ & $29,8(2,439)$ \\
\hline Születési & 962 & 817 & 1233 & 1174 \\
testtömeg (g) & $(38,68)$ & $(39,01)$ & $(255,94)$ & $(253,19)$ \\
\hline Mintaelemszám & 27 & 24 & 81 & 117 \\
\hline
\end{tabular}

2. táblázat: A születési testtömeg és a gesztációs időtartam átlagai a vizsgált koraszülött csoportban (szórás) 
A fejlődési vizsgálatokat a Brunet-Lézine-féle pszichomotoros fejlődési skálával végeztem, melynek hazai adaptálását a Gyógypedagógiai Tanárképző Főiskolán Csiky Erzsébet vezetésével végezték el, 526 pszichomotoros státusz elemzése alapján.

A fejlődési skála négy területen mér: nagymozgások $(P Q)$, finommotoros koordináció $(K Q)$, beszéd $(B Q)$ és szociabilitás $(S z Q)$. A teszt eszköz-szükséglete minimális: fa kockák, csengő, tükör, pasztillák, formatábla, mesekönyv, ceruza. A vizsgálatot a szülő jelenlétében végezzük el. A részletes instrukciók segítségével standard vizsgálati helyzet teremthető. A próbák sorrendjénél figyelembe vesszük a gyermek érzelmi irányultságát, spontán érdeklődését, aktuális lelki állapotát. A teszt próbákat és kérdéseket tartalmaz. A gyerek teljesítményét profil-lapon ábrázoljuk. A teljesített próbák pontértékei alapján kapjuk meg a fejlődési kor mutatót. Koraszülöttek esetében 24 hónapos korig a korrigált életkort vesszük figyelembe (a naptári életkort korrigáljuk a koraszülöttség mértékével). A teljesítmény és a korrigált életkor alapján fejlődési hányadost (FQ)-t számolhatunk. $A$ fejlődési hányadost kórosnak tekintjük, ha értéke 70 alatt van.

A vizsgálatokat 10-22 hónapos kor között végeztük el.

\section{Koraszülöttek gyakori társuló betegsége - Bronchopulmonális diszplázia (BPD)}

A koraszülöttek körében az egyik leggyakrabban megjelenő orvosi komplikáció, biológiai rizikó a BPD (Lewis, Singer és Fulton, 2002). A bronchopulmonális dysplasiát először Northway és munkatársai írták le 1967-ben (Northway, 1967). Manapság a BPD jellemzően az igen kis testtömeggel születettek körében gyakori. A BPD multifaktoriális etiológiájú betegség. Kialakulásában egyaránt szerepet játszanak prenatális és postnatális tényezők (beleértve gépi lélegeztetést, oxigén toxicitást és fertőzéseket), melyek megszakítják a tüdő fejlődését, és károsítják a sérülékeny koraszülött tüdőt (Laughon, 2009).

A BPD-t klinikailag az elhúzódó légzéstámogatási igény, elsősorban oxigén dependencia jellemzi. A krónikus hypoxia (oxigénhiányos állapot) miatt a fejlődés elmarad, perifériás cianózis (a végtagokon a bőr színének kékes-lilás színű elváltozása), dobverőujj alakulhat ki. A növekedés és fejlődés elmaradásához hozzájárul a fokozott légzési munka miatt megnövekedett energiaigény is. „Mivel minden energiáját légzésre fordítja a gyermek, másra nem marad ereje" (Deakins, 2009). Ezzel magyarázható a táplálási nehezítettség is, ami tovább súlyosbítja a retardációt. A szomatikus elmaradások mellett idővel mentális visszamaradás is kialakulhat. Ebben nagy szerepe van a gyakori, elhúzódó hospitalizációnak is. A betegek a legyengült szervezet és a károsodott tüdő miatt fokozottabban érzékenyek a fertőzésekre, hajlamosak a tüdőgyulladásra. A légzészavart a fertőzések és a szervezetet érő egyéb stressz-hatások jelentősen súlyosbíthatják. Ilyenkor még a látszólag panaszmentes gyermekek is rövid időn belül légzéstámogatásra, gyakran gépi lélegeztetésre szorulhatnak. Ezáltal egy önrontó kör alakulhat ki. Az állandó gyulladás tovább roncsolja a tüdőállományt, a beteg ezért egyre rosszabb állapotba kerül, miközben egyre fogékonyabb a fertőzésekre (Lancet, 2006; Deakins, 2009).

\section{Az egyes alcsoportok fejlődési mutatóinak leíró statisztikája - 12 hónaposnál fiatalabbak fejlődési mutatói (szórás)}

A táblázatban szereplő rövidítések: $B Q$ : beszédfejlődési mutató, $F Q$ : fejlődési hányados, KQ: finom motoros koordináció, $P Q$ : nagymozgás mutató, SzQ: szociabilitás mutató 
Koraszülöttség és fejlődési kimenet

\begin{tabular}{|l|c|c|c|c|c|}
\hline Csoport (mintaelemszám) & BQ & FQ & KQ & PQ & SzQ \\
\hline BDP fiú, <12hó (12) & $86,25(26,12)$ & $97,92(9,73)$ & $92,67(21,48)$ & $90,92(22,87)$ & $91,33(23,16)$ \\
\hline BDP lány, <12 hó (16) & $92,62(12,92)$ & $93,12(9,69)$ & $94,75(11,58)$ & $92,56(8,89)$ & $92,25(8,96)$ \\
\hline nem BDP fiú, <12hó (39) & $96,54(14,95)$ & $99,69(10,4)$ & $100,5(9,79)$ & $102,41(12,86)$ & $96,53(9,72)$ \\
\hline nem BDP lány, <12 hó (52) & $97,08(11,88)$ & $99,4(9,35)$ & $98,8311,25)$ & $102,19(10,65)$ & $97,76(10,18)$ \\
\hline
\end{tabular}

3. táblázat: Az egyes alcsoportok fejlődési mutatóinak leíró statisztikája - 12 hónaposnál fiatalabbak fejlődési mutatói (szórás)

\begin{tabular}{|l|c|c|c|c|c|}
\hline Csoport (mintaelemszám) & BQ & FQ & KQ & PQ & SzQ \\
\hline BPD fiú, >12 hó (15) & $69,67(22,02)$ & $78,53)(16,28)$ & $75,93(23,84)$ & $73,73(21,39)$ & $77,07(19,74)$ \\
\hline BPD lány, >12 hó (8) & $84,2586,86)$ & $90,0(5,32)$ & $90,25(6,11)$ & $90,12(5,91)$ & $91,25(6,34)$ \\
\hline nem BPD fiú, >12 hó (42) & $92,52(12,31)$ & $95,14(10,71)$ & $94,21(10,84)$ & $98,05(14,43)$ & $94,05(10,38)$ \\
\hline nem BPD lány, >12 hó (65) & $91,2(11,97)$ & $93,35(9,78)$ & $94,23(11,57)$ & $95,82(12,3)$ & $92,31(10,9)$ \\
\hline
\end{tabular}

4. táblázat $A z$ egyes alcsoportok fejlődési mutatóinak leíró statisztikája - 12 hónaposnál idősebbek fejlődési mutatói (szórás)

A koraszülött gyerekek csoportját bontottuk a BPD megléte, a nem és az életkor szerint (12 hónaposnál fiatalabbak, és 12 hónaposnál idősebbek) csoportokra. A fejlődési mutatók elemzését lineáris modellekkel végeztük.

\section{A fejlődési hányados (FQ)}

Szignifikáns különbség áll fenn a két életkori csoport között. A 12 hónaposnál idősebbek pontszámai alacsonyabbak. A BPD-s csoporton belül a lányok mutatói magasabbak. A nem BPD-s fiúk lényegesen jobban teljesítettek, mint a BPD-s fiúk.

\section{A nagymozgás függő változó (PQ)}

Szignifikáns különbség áll fenn a két életkori csoport között. A 12 hónaposnál idősebbek pontszámai alacsonyabbak. A BPD-s csoporton belül a lányok mutatói magasabbak. A nem BPD-s fiúk lényegesen jobban teljesítettek, mint a BPD-s fiúk.

\section{A koordinációs mutató (KQ) függő változó}

Szignifikáns különbség áll fenn a két életkori csoport között. A 12 hónaposnál idősebbek pontszámai alacsonyabbak . A BPD-s csoporton belül a lányok mutatói magasabbak. A nem BPD-s fiúk lényegesen jobban teljesítettek, mint a BPD-s fiúk.

\section{A beszéd kvóciens (BQ) függő változó}

Szignifikáns különbség áll fenn a két életkori csoport között. A 12 hónaposnál idősebbek pontszámai alacsonyabbak. A BPD-s csoporton belül a lányok mutatói magasabbak. A nem BPD-s fiúk lényegesen jobban teljesítettek, mint a BPD-s fiúk.

\section{A szociabilitás mutató (SzQ) függő változó}

A szociabilitás mutató (SzQ) vonatkozásában szintén a korkategóriák szerint mutatkozik jelentős különbség mind a BPD-s, mind a nem BPD-s csoportban, a 12 hónaposnál 
idősebbek pontszámai alacsonyabbak. A BPD-s csoporton belül a lányok mutatói magasabbak. A nem BPD-s fiúk lényegesen jobban teljesítettek, mint a BPD-s fiúk.

Kutatásunk eredménye alapján bebizonyosodott, hogy a csecsemőkorú igen kis születési testtömegű koraszülött gyerekek esetében egy társuló betegség jelentősen rontja a fejlődési kimenet szintjét. Az igen kis születési testtömegü, egészséges koraszülöttek minden fejlődési mutatója az átlagos övezetben helyezkedett el, addig a BPD-sek mutatói jelentősen alacsonyabbak voltak, különösen a fiúk beszéd mutatóit illetően. Az életkori bontás alapján láttuk, hogy az alulteljesítés mértéke az életkor haladtával növekszik, nem zárkóznak fel, nem hozzák be lemaradásukat. Mindezek ismeretében fontosnak tartanánk a szakemberek és a szülők tájékoztatását, és a korai intervenció kellő időben történő megkezdését a BPD-s, mérsékelt rizikójú koraszülöttek esetében, a későbbi tanulási és viselkedési problémák megelőzése céljából.

A szakirodalomban néhány longitudinális kutatás számolt be arról, hogy míg kisgyermekkorban szignifikáns hátrányt tapasztaltak koraszülötteknél, 19 éves korra ez jelentős mértékben csökkent, az iskolázottság foka nem különbözött a kontroll csoporttól. Ez az eredmény a koraszülöttek felzárkózását tükrözi (Tideman, 2000).

Más kutatási beszámolók viszont azt jelezték, hogy a koraszülöttek hátránya hoszszú ideig fennáll és tetten érhető, esetleg az életkor növekedésével fokozódhat is (Aylward, 2002; Kalmár, 2007; Saigal et al., 2000). Egyes kutatások az iskolába kerülés időpontjában tapasztaltak olyan fejlődésbeli hiányosságokat, elmaradásokat, amikre a megelőző életkorokban végzett vizsgálatok alapján nem számítottak (Cohen, Beckwith és Parmelee, 1996).

Egészen bizonyos, hogy az időtényező nem elhanyagolható a rizikó hosszú távú hatásának megítélésében. Erre utal az „alvó hatás” elmélet (Wrape, 2003 in: Ribiczei és Kalmár), amely egy a korai életkorból származó rizikó későbbi életkorban megvalósuló lehetséges hatására utal (Ribiczei és Kalmár, 2012).

Még érthetőbb az életkor-fejlődési kimenet összefüggés a Gordon és Jens által javasolt „mozgó rizikó” modell segítségével (Gordon és Jens, 1988). Egy probléma eltúnése egy adott életkorban nem jelenti azt, hogy a hátrány, amely nem független ettől a korábban jelentkezett állapottól, később ne jelenjen meg újra. Ezek az állapotok egymást válthatják folyamatosan. Reziliencia esetén (a veszélyeztető környezet ellenére megfelelő alkalmazkodás) sem lehetünk biztosak abban, hogy a későbbiek során is hasonló marad az állapot (Masten, 2001; Rutter, 2007).

S. A. Rose és munkatársai számos, alapos kutatási eredménnyel támasztották alá azt, hogy koraszülött gyerekek esetében már a nagyon korai információfeldolgozási folyamatok (figyelem, feldolgozási sebesség) is eltérően alakulnak és ez vezethet a később megjelenő kognitív deficit kialakulásához. Az átlagos övezet alsó harmadában elhelyezkedő IQ-t (átlagosan 10 ponttal alacsonyabb, mint a kontroll csoporté) pedig a korai életkortól megnyilvánuló gyenge információfeldolgozási folyamatok következményének tekintették. Álláspontjuk szerint a koraszülöttség egy pervazív kognitív képességzavar, amely kognitív képességdeficitekkel jár. A koraszülöttek IQ-ja az időre született gyerekekhez képest általában alacsonyabb, bár a normál övezetben van. Gyengébb az iskolai teljesítményük, különösen a matematika terén. Egy 15 tanulmány eredményeit összegző elemzésböl az derült ki, hogy a két csoport közötti súlyozott átlag-különbség mintegy 10 pont (Rose, Feldman és Jeffry, 2011).

\section{Koraszülöttség és iskolai teljesítmény}

Az igen kis születési testtömegű gyerekek közel 50\%-ának nem megfelelő az iskolai teljesítménye vagy viselkedésproblémákkal küzd az USA-ban (Inder, 2005). Számos 
kutatócsoport állapította meg, hogy koraszülöttek körében nagyobb valószínűséggel jelenik meg tanulási zavar, a tananyag elsajátítása nehezebb és gyakran alacsonyabb az iskolai teljesítményük, mint az időre született társaiké (Saigal, Szatmari és Rosenbaum, 2008).

Johnson és Breslau kis születési testtömegű koraszülöttek körében vizsgálták a tanulási zavar előfordulási gyakoriságát. Megállapították, hogy a fiúk között nagyobb gyakorisággal jelenik meg olvasás és számolási zavar, mint az időre születettek között. A koraszülött fiúk 15,2\%-a volt érintett olvasászavar kapcsán, a lányoknak csak $7 \%$-a. A számolási zavar megjelenési gyakorisága 10,9\% fiúknál és $4,1 \%$ a lányoknál (Breslau, Johnson és Luca,2001).

Erre vonatkoznak saját kutatási eredményeink 8-11 éves kor közötti koraszülött gyermekekre vonatkozóan, akik $1500 \mathrm{~g}$ alatti születési testtömegü, negatív neurológiai státuszú, mérsékelt rizikójú koraszülöttek voltak. A 28-33. gesztációs hétre születtek, 990-1350g közötti születési testtömeggel.

Az olvasás-, helyesírászavar megállapítása céljából a 3DM (Dyslexia Differential Diagnosis, Maastricht) számítógépes vizsgálat magyar változatának (3DM-H) olvasás szürő programját alkalmaztuk. (Az eredeti változatát Leo Blumert és Anniek Vaessen dolgozta ki. A magyar verzió: Copyright Tóth Dénes, Csépe Valéria, Anniek Vaessen és Leo Blumert $3 \mathrm{DM}-\mathrm{H}, \mathrm{Az}$ olvasás és helyesírás kognitív elemzése). A teszt adaptációja jelenleg kidolgozás alatt áll. A vizsgáló eljárást prof. Dr. Csépe Valéria hozzájárulásával alkalmaztuk.

A 3DM-H mérőeszköz a szóolvasás és helyesírás pontosságát és fluenciáját méri. A 3DM-H szürővizsgálat során, a számítógép képernyőjén fél percig megjelenített, egyre nehezedő ortográfiájú és szóhosszúságú, gyakori, ritka és álszavak jelennek meg, amit hangosan olvasnak fel a gyerekek. A helyesírás szintjének felmérése során, a képernyőn hiányos szavak jelennek meg, a gyerekeknek ki kell egészíteni a szavakat a felkínált betűk közül, a megfelelő gomb megnyomásával. A mért mutatók: olvasáspontosság (olvpont), olvasásfluencia (olvflu), íráspontosság (irpont), írássebesség (irseb).

\begin{tabular}{|l|c|c|c|c|}
\hline \multicolumn{1}{|c|}{ Csoport } & $\begin{array}{c}\text { olvasás- } \\
\text { pontosság }\end{array}$ & olvasásfluencia & íráspontosság & írássebesség \\
\hline Koraszülött (23) & 52,6 & 53,3 & 51,5 & 49,2 \\
Diszlexiás (27) & 31,1 & 33,5 & 36,8 & 41,8 \\
\hline Jól olvasó (30) & 54,8 & 55,5 & 52 & 50,7 \\
\hline
\end{tabular}

5. táblázat: Az olvasás- és helyesírás-mutatók alakulása

Ebben az esetben a mi vizsgálati eredményeink nem esnek egybe a szakirodalomban korábban említett eredményekkel. A feltételezéssel szemben a koraszülöttek teljesítménye az olvasás és az írás terén nem különbözik a rizikómentes kontroll csoportétól. A kedvező eredmény értelmezéséhez figyelembe kell venni a koraszülöttek teljesítménymintázatát is, nevezetesen, hogy a kognitív hátrányuk nem érinti a munkamemóriát. Hangsúlyoznunk kell, hogy a koraszülött csoport tagjai a mérsékelt rizikójú kategóriába tartoztak, míg a feltételezéseinket megalapozó kutatási eredmények többnyire súlyosabban veszélyeztetett koraszülöttek vizsgálatából származtak. 


\section{Javaslat}

A koraszülött gyerekek fejlődése nem mondható általában problémamentesnek. A kis elmaradások, az alacsonyabb intelligenciamutatók az iskolás korra összegződhetnek és jelentősen ronthatják az iskolai teljesítményt, másodlagosan viselkedési problémák megjelenéséhez vezethetnek. Szükségesnek tartjuk a rendszeres utánvizsgálatot iskoláskorig, szükség esetén a kellő időben megkezdett intervenciót.

\section{Irodalom}

Aylward, G. P. (2002): Cognitive and neuropsychological outcomes: More than IQ scores. Mental Retardation and Developmental Disabilities. Research Reviews, 8. 234-240.

Breslau, N. Johnson, N. és Lucia, V. C. (2001): Academic achievement of low birthweight children at age 11: the role of cognitive abilities at school entry. Journal of Abnormal Child Psychology, 29. (4) 273-279.

Kalmár Magda (2007): Az intelligencia alakulásának elörejelezhetősége és váratlan fordulatai. Rizikómentesen született, valamint koraszülött gyerekek követésének tanulságai. ELTE Eötvös Kiadó, Budapest.

Katona Márta és Orvos Hajnalka (2005): Az intenzív újszülött ellátás aktuális kérdései. Gyermekgyógyászati Továbbképző Szemle, 10. (3) 105-109.

Laughon, M., Brian M., Smith P. és Bose C. (2009): Prevention of bronchopulmonary dysplasia. Seminars in Fetal and Neonatal Medicine. 14. 374-382

Lewis, B. A., Singer, L. T., Fulton, S., Salvator, A. et al (2002): Speech and language outcomes of children with bronchopulmonary dysplasia. J Comm Disord. 35. 393-406.

Nagyné Réz llona, Lányiné Engelmayer Ágnes, Kuncz Eszter, Mészáros Andrea, Mlinkó Renáta, Bass László, Rózsa Sándor és Kő Natasa (2008): A WISC-IV gyermek intelligenciateszt magyar kézikönyve. Hazai tapasztalatok, vizsgálati eredmények és normák. OS Hungary Tesztfejlesztö Kft., Budapest.

Nortway, W. H., Rosan, R. C. és Porter D.,Y. (1967): Pulmonary disease following respiratory therapy of hyaline membrane disease: bronchopulmonary dysplasia. $N$ Eng J Med., 357-368.

Ribiczey Nóra és Kalmár Magda (2009): A „mozgó rizikó” koraszülött gyerekek fejlődésének tükrében. Alkalmazott Pszichológia, 10. (1-2.) 103-123.

Rose, S. A., Feldman, J. F., Jeffery, J., Jankowski R. és R. Van Rosem (2011): Basic information processing abilities to 11 years account for deficit in IQ. Intelligence, 39. 198-209.

Saigal, S., Szatmari, P., Rosenbaum, P., Campbell, D. és King,S. (1991): Cognitive abilities and school performance of extremly low birth weight children and matched term controll children at age 8 years: a regional study. J.Pediatr.; 118. 751-760.

Saigal, S., Hoult, L. A., Streiner, D. A., Stoskopf, B. L. és Rosenbaum, P. L. (2000): School difficulties in adolescence in a regional cohort of children who were extremely low birth weight. Pediatrics, 105. 325-331. 